survive political violence, the impact of national identity discourse on politics and violence, and the place of antisemitism in fascist ideologies. His argument on the role of antisemitism as a trigger of political violence is particularly revealing. He theorizes political antisemitism as a "dynamic political phenomenon" (11), contingent upon the electoral politics of the 1920s. Like Scott Ury, in his Barricades and Banners: The Revolution of 1905 and the Transformation of Warsaw Jewry, Brykczynski focuses on the relationship "between the dynamics of electoral politics in Russian-ruled Poland, on the one hand, and radicalization and disseminations of political antisemitism among the masses, on the other" (4). But, unlike Ury, he "place[s] more weight on the role of contingent variables in structuring the discourse of the nation [and minorities] during electoral contests" (4). He makes a convincing argument that the distinctive electoral system and parliamentary results (in the context of the debate over the meaning of Polishness) made it possible for the radical right (politicians and press) to turn vague antisemitic resentment into the concrete and urgent "Jewish threat," which then led to Narutowicz's murder and anti-Jewish violence on the streets of Warsaw. This sophisticated and theoretically rich analysis secures Primed for Violence an important place in the scholarship on the role of antisemitism in European history.

Primed for Violence is a case study in political history which draws heavily on extensive primary sources: press articles, electoral pamphlets, parliamentary and police records as well as memoirs of relevant political figures. This selection of sources firmly grounds Brykczynski's narrative in the city of Warsaw without affording insight into the impact of the assassination outside the capitol. For example, municipal records outside Warsaw would allow the author to test his argument on the role of the assassination in the political left's abandonment of minorities on a national scale. The lack of sources from Warsaw parishes also precludes analysis of the role of the Catholic Church. However, these omissions should not be seen as a weakness but as an invitation for more research by historians fluent in a variety of methods. For example, social historians can further build on Brykczynski's study by investigating the social and cultural bases for receptivity to antisemitism among university students who seemed particularly active in the anti-Jewish riots in Warsaw in December 1922. While there is substantial scholarship on the fascist youth in Germany and Italy, the young of the Polish Endecja still await analysis.

Brykczynski's book is an outstanding and welcome contribution to scholarship on Polish nationalism, the history of antisemitism, political violence, fascism, and democratic politics. Well written with accessible prose, it will resonate with the public at large as we grapple with contemporary challenges to democracy across the globe.

ANNA CiCHOPEK-GAJRAJ Arizona State University

Poland and Polin: New Interpretations in Polish-Jewish Studies. Ed. Irena Grudzińska-Gross and Iwa Nawrocki. Eastern European Culture, Politics and Societies, Vol. 10, eds. Irena Grudzińska-Gross and Andrzej W. Tymowski. Frankfurt am Main: Peter Lang GmBH, 2016. xvi, 229 pp. Appendix. Notes. Index. Illustrations. $\$ 60.95$, hard bound.

doi: $10.1017 /$ slr.2017.203

Between the unveiling of the core exhibition of the POLIN Museum of the History of Polish Jews in October of 2014 and the initiation of the design process of this project in 1993, several teams of specialists and numerous members of the general public discussed the profile and content of the museum. Among hundreds of discussed issues, 
there were two dominating heated controversies: how to present the Holocaust and a history of antisemitism in Poland. The book under review is a continuation of this debate and is based on the presentations delivered during the Princeton University Conference on Polish-Jewish Studies in April 2015.

The volume opens with the "Conference report" by Geneviève Zubrzycki, the Conference Rapporteur and a Professor of Sociology at the University of Michigan, who describes all the six panels of the conference. A reader can see that only ten of the twenty-one presentations are published. The editors of the volume do not explain this selection beyond a statement: "Not all the papers delivered during the conference were presented for this publication, and none was submitted by the speakers professionally involved in POLIN . ..” (7). Indeed, all three presenters of the first panel (Rethinking Historical Narratives: The POLIN Museum of the History of Polish Jews), Dariusz Stola, the Director of the Museum; Samuel Kassow, a Professor of Trinity College and the creator of the interwar exhibition; and Marcin Wodziński, a Professor of the Wrocław University and a historical consultant of the Museum, did not submit the texts of their presentations. Among other participants that also did not submit are Michael Steinlauf from Gratz College, Beth Holmgren from Duke University, and Karolina Szymaniak from the Jewish Historical Institute in Warsaw.

One can easily observe that a majority of the submitted texts are critical of the Museum. Their authors offer many strong and convincing arguments, but frequently the critical voices are radical and exaggerated. Jan Grabowski, a Professor of the University of Ottawa, analyzes the "historical policy" of the Polish authorities and shows how they abuse the memory of the Polish Righteous Among the Nations, the Żegota Council for Help to the Jews, Jan Karski, Irena Sendler, and others, all in order to cover up difficult or shameless episodes of Polish history and to de-Judaize the Holocaust. Jan T. Gross describes the most important factors contributing to antisemitism in Poland during the Second World War. Irena Grudzińska-Gross, the organizer of the conference and Professor at Princeton University, writes about Polish defensive myths. Joanna Tokarska-Bakir, Professor at the Princeton Institute for Advanced Study and the Polish Academy of Sciences, criticizes the program of the Museum and claims that POLIN "does not require the audience to reflect upon difficult issues" (55); "has created a subtle and nuanced "Polish response" to this accusation" [that a number of Poles contributed to the execution of the Final Solution] (51); and "deemphasizes Jewish martyrdom” (58).

Piotr Matyjaszek from the Polish Academy of Sciences critically analyzes the strategies of the creators of the Museum, and writes about "the Polonization of Jewish History" at POLIN. Piotr Forecki from the University of Poznań and Anna Zawadzka from the Polish Academy of Sciences repeat the argument of their predecessors that "the main task of the Museum of the History of Polish Jews is to protect the image of Poland and Poles" (108).

The volume is dominated by a fifty-page-long text by Elżbieta Janicka, a scholar from the Polish Academy of Sciences and an artist-photographer. She argues that "the present-day space around the Monument [to the Fighters and the Martyrs of the Ghetto] and the Museum is a manifestation of the narrative pattern characteristic of the dominant Polish narrative of the Holocaust," which "is drastically different from the actual facts" and "is characterized by the dynamics of an obsessive-compulsive disorder" (122). Janicka writes about the "de-Judaization of the Holocaust," "Polonization," "the decontextualization of Jewish history" (136), and "the Polish myth," which is "the Museum's master narrative." "And it is not only a narrative," adds Janicka, "it is also a principle that delegitimizes alternative narratives" (140). She is not shy about presenting risky historical interpretations and claims, for example, that Żegota "was established and exploited by the Polish Underground State for propaganda and financial 
purposes" (159). POLIN, concludes Janicka, "not only does not challenge, but downright perpetuates and transmits, and therefore legitimizes and consolidates constructions which are at home in a museum of anti-Semitism" (161).

Zubrzycki's "Problematizing the 'Jewish Turn"” offers a more balanced view of the Museum's narrative. Karen Underhill, a co-organizer of the conference and a professor of the University of Illinois at Chicago, and Erica Lehrer, a professor of Concordia University, tentatively defend the Museum and the arguments of those who did not submit their presentations. Lehrer writes about "the difficult encounter between scholars" during the conference (197) and quotes Michael Steinlauf, who "noted with some incredulity that in their rhetoric these politically left-wing Poles might have been mistaken for right-wing Jews" (198). Lehrer understands the radical critics" "extreme rhetoric" but calls it a "monotone, 'sledgehammer' approach" (211).

It is unfortunate that we can follow only one side of the discussion, considering that POLIN was granted the prestigious 2016 European Museum of the Year Award (EMYA). The jury appreciated both the quality of the museum's core exhibition presenting 1000 years of Polish-Jewish coexistence and the Museum's educational, academic, and social programs. In 2016, POLIN was also granted the EMA (European Museum Academy) Prize. To quote the jury statement: "the POLIN Museum is not just an excellent museum but a state of art cultural institution that reaches a diverse public all over the world. That is why it deserves the title of a 'Total Museum.”'

PIOTR J. WRÓBEL University of Toronto

\section{London's Polish Borders. Transnationalizing Class and Ethnicity among Polish Migrants in London. By Michał Garapich. Stuttgart: Ibidem-Verlag, 2016. 344 pp. Notes. Bibliography. Photographs. Tables. \$39.00, paper. doi: 10.1017/slr.2017.204}

The June 23, 2016 referendum in the United Kingdom yielded a 52 to 48 percent vote in favor of the country's exit (Brexit) from the European Union. Michał Garapich's monograph of Poles living transnational lives between London and Poland was published on the eve of this momentous event, but it will have landed in the hands of most readers in the aftermath. It is therefore destined to be read and commented upon with the benefit of hindsight. Voters who chose Brexit based their decisions on a variety of factors. However, according to the prevailing consensus, the key issue that soured vast sections of the British public on the idea of EU membership was the sharp rise in immigration from eastern Europe in the little more than a decade since the eastward expansion of the European Union in 2004. At the time, the government chose not to impose restrictions on the freedom of movement of citizens of newly admitted member states which, in the case of Poles, resulted in nearly a tenfold increase in the numbers residing in the UK, registered between the 2001 census $(60,000)$ and the 2011 census $(570,000)$.

Garapich duly cites these figures in the Preface and contends, somewhat optimistically from a post-referendum perspective, that the impact "on the economy, welfare, and society in general has been positive." Nevertheless he allows that "indirectly and partially, the massive movement from Poland to the UK resulted in the rise of antiimmigrant parties like the United Kingdom Independence Party and in increased pressure on the British political class to call for an in-out EU referendum” (19). The book is "about the people behind this process" (19). Indeed, with considerable ethnographic skill and historical depth, Garapich fleshes out the complexities and contradictions of the many meanings of being a "Polish migrant" in London. Most of his impressive body 